ISSN 0258-7122

Bangladesh J. Agril. Res. 35(1) : 37-50, March 2010

\title{
GROWTH AND YIELD PERFORMANCE OF DIFFERENT GENERATIONS OF SEED POTATO AS AFFECTED BY PVY AND PLRV*
}

\author{
M. S. RAHMAN ${ }^{1}$, A. M. AKANDA ${ }^{2}$, I. H. MIAN ${ }^{3}$ \\ M. K. A. BHUIAN ${ }^{4}$ AND M. R. KARIM ${ }^{5}$
}

\begin{abstract}
Performance of potato seed tubers of first, second, third, fourth, and fifth generations were evaluated against PVY and PLRV. Potato plants grown from first generation seed tubers were free from PVY infection. Incidence of the virus was the minimal at second generation, which increased afterwards steadily by third, fourth, and fifth generations. Incidence of PLRV was minimal at first generation. It increased gradually with the advancement of generation seed tubers showing the highest incidence at fifth generation. The highest plant growth and tuber yield were recorded at second generation, which was followed by third, fourth, and fifth generations. The highest reduction in plant height, tuber number, and tuber yield were recorded in $5^{\text {th }}$ generation due to infection of PVY and PLRV.
\end{abstract}

Keywords: Generation evaluation, PVY, PLRV, growth, yield, potato.

\section{Introduction}

The gradual decomposition of genetic potential is referred to degeneration, which is a world wide problem of maintaining stability of potato yield. The degeneration of potato is appeared to be either due to physiological causes or due to infection of tuber-borne viruses, especially PVY awl PLRV (Chandla et al., 2001). Physiological degeneration can be recovered through proper crop management, but degeneration due to virus can hardly be overcome. Thus the degeneration problem of potato seed tubers due to PVY and PLRV is considered to be the most severe constraint to potato cultivation. It is the most tenacious problem of potato seed tubers resulting spontaneous yield deterioration of the crop (Singh et al., 1982). PVY and PLRV have also been reported to be highly prevalent in Bangladesh as reported by Rashid et al (1986). The possibility to ensure the high yield of potato remains to a great extent with management of these two viruses.

It has been recognized that the poor yield of potato is attributed to the use of virus infected seed potato, especially seed potato having infection with PVY and

\footnotetext{
*Part of Ph.D Dissertation.

${ }^{1} \mathrm{Ph} . \mathrm{D}$ Student of BSMRAU \& Upazilla Agriculture Officer, Gazipur Sadar, Gazipur, ${ }^{2,3 \& 4}$ Professor, Department of Plant Pathology, BSMRAU, Gazipur 1706, ${ }^{5}$ Deputy Director, BADC, Dhaka, Bangladesh.
} 
PLRV (Sawicka, 1994; Khurana et al, 1998). The sccd potato infected with PVY and PLRV seems to be degenerated following the successive generation (Hussain et al., 1972; Tien et al., 1982; Bari et al., 1998). This is also an acute problem of seed potato production in Bangladesh (Klian et al., 1991). So, it is highly important to evaluate the denegation behaviour of potato due to infection of PVY and PLRV.

Under the above circumstances, the present experiment was conducted to study the performance of five generations of seed potato against PVY and PLRV and their effect on plant growth and yield potential.

\section{Materials and Method}

Seed tubers of Diamant, a commonly cultivated potato variety in Bangladesh, representing five different generations, namely $1^{\text {st }}, 2^{\text {nd }}, 3^{\text {rd }}, 4^{\text {th }}$, and $5^{\text {th }}$ generations were used in the experiment. The experiment was conducted in two consecutive crop seasons of 2004-'05 and 2005-'06 at the experimental field of Bangabandhu Sheikh Mujibur Rahman Agricultural University (BSMRAU), Salna, Gazipur, in 2004-05 $1^{\text {st }}, 2^{\text {nd }}, 3^{\text {rd }}, 4$ th, and $5^{\text {th }}$ generations seed potato were planted. The seed potato obtained from 2004-'05 was planted in the subsequent year of 2005-'06, where advancement occurred in each of the generations.

Fertilizers were applied at 350-250-270-120-120-106 kg/ha of urea, TSP, MP, gypsum, magnesium sulphate, zinc sulphate, and borax, respectively, as recommended for the country (Anon. 2004). One half of urea and full dose of all other fertilizers were applied at the time of planting. Other half of urea was applied as side dressing after 35 days of planting when first earthling up was done. During land preparation, cowdung was applied at $10 \mathrm{t} / \mathrm{ha}$. The seeds were planted in the field on 22 November and the crop was harvested on 4 March. Dining both the crop seasons of 2004-05 and 2005-06, seed tubers were preserved in the cold storage. Whole tubers were planted maintaining $60 \mathrm{~cm}$ row to row and $25 \mathrm{~cm}$ seed to seed distances. The experiment was laid out following randomized complete block design (RCBD) with four replications. The unit plot size was $3 \mathrm{~m} \times 3 \mathrm{~m}$. Intercultural operations, such as irrigation, weeding, mulching, and earthling up were done as and when necessary. Fungicide, Ditbane M-45 was applied at $0.25 \%$ to protect the crop from fungal diseases. No insecticide was used in the field. Before haulm pulling virus infected plants were identified studying symptoms of the diseases and confirmed using indicator plants (Hill, 1984) and DAS-ELISA following the fundamental protocol outlined by Clark and Adams (1977) and modified by Akanda et al (1991). Symptoms appeared on infected plants were compared with standard symptoms of PVY and 
PLRV (Hooker, 1981). Before harvest, haulm pulling was done and data on the incidence of PVY and PLRV, plant height, stem number, tuber number, and tuber yield per plant were recorded.

Disease incidence and yield loss was calculated using the following formula: Disease incidence $(\%)=($ Number of infected plants $/$ Total plants $) \times 100$

Yield reduction $(\%)=(\mathrm{A}-\mathrm{B}) / \mathrm{A} \times 100$, where $\mathrm{A}=$ Yield of healthy plant, $\mathrm{B}=$ Yield of diseased plant.

Data were analysed using Duncan Multiple Range Test.

\section{Results and Discussion}

\section{Incidence of PVY and PLRV}

Incidence of PVY and PLRV were identified based on characteristic symptoms of the viruses appeared on plants. At advanced stage of disease development, severity of PVY and PLRV infection and their mixed infection varied with generations of potato seed tubers. The incidence of PVY was not observed in first generation. The PVY was first appeared in $2^{\text {nd }}$ generation and its incidence increased gradually with the increase of crop generations. Disease incidence ranged 0.00 to $11.14 \%$ in different generations in crop season of 2004.05 (Fig. 1), whereas it varied $4.58 \%-18.33 \%$ in crop season 2005-06 (Fig. 2). The highest incidence of PVY was observed in $5^{\text {th }}$ generation and $6^{\text {th }}$ generation in 2004-05 and 2005-06, respectively. The percent infection of PLRV ranged 1.27\%-7.65\% in 2004-05 (Fig. 1) and 3.67\%-13.33\% in 2005-06 (Fig. 2). In both of the years, the incidence differed significantly $(\mathrm{P}=0.01)$ among different generations. Mixed infection of PVY and PLRV was found lower as compared to PVY and PLRV. Percentage of mixed infection ranged $0.00-5.10 \%$ (Fig. 1) in cropping season 2004-'05. There was no mixed infected plants in $1^{\text {st }}$ generation. It first appeared in $2^{\text {nd }}$ generation and differed significantly with rest of the generations. Statistically similar incidence of mixed infection was observed in $3^{\text {rd }}, 4^{\text {th }}$ and $5^{\text {th }}$ generations. In cropping season 2005-06, mixed infection ranged $2.07 \%$ to 7.08 \% (Fig. 2).

Results of the present study are in agreement with the findings of Hossain et al. (1994), Bari et al (1998), Hossain (1999), Yardimic and Bostan (1999), Wolf and Horvath (2000); Amitava et al. (2001); Choneiri et al. (2004). 


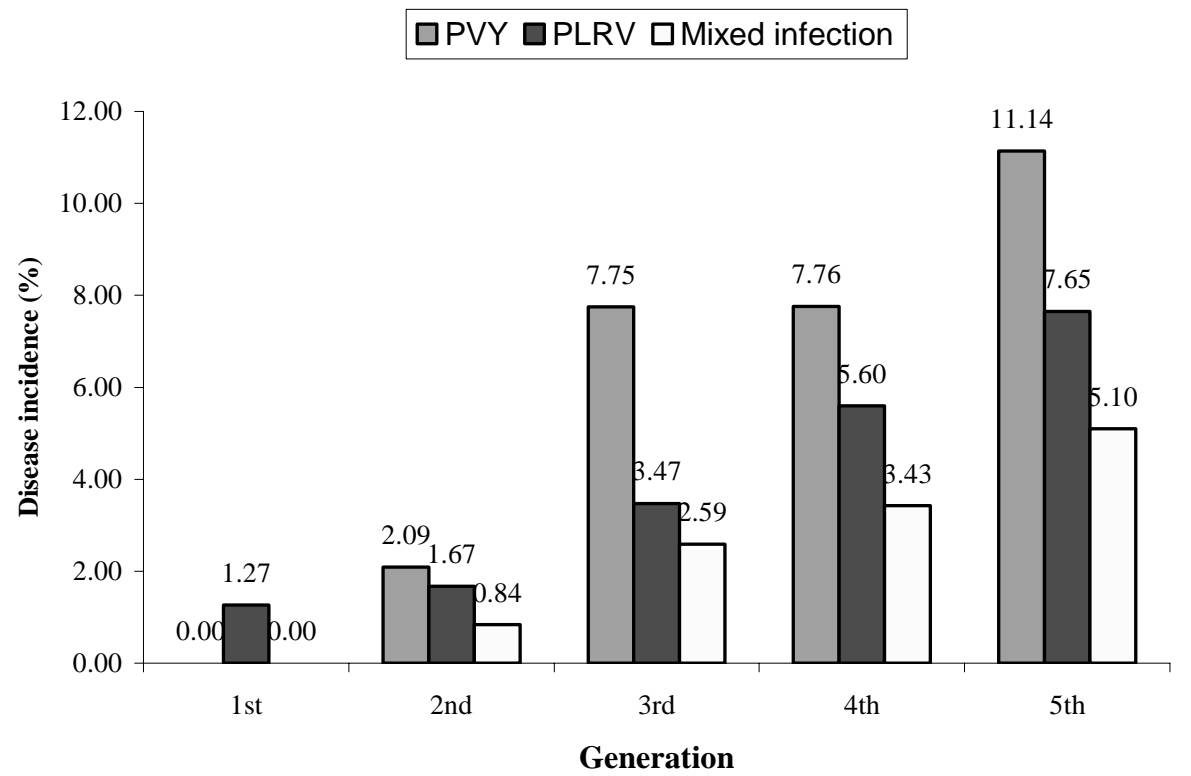

Fig. 1. Incidence of PVY, PLRV and mixed infection of both the viruses on five successive generations of potato grown in 2004-05 crop season.

\section{$\square$ PVY $\square$ PLRV $\square$ Mixed infection}

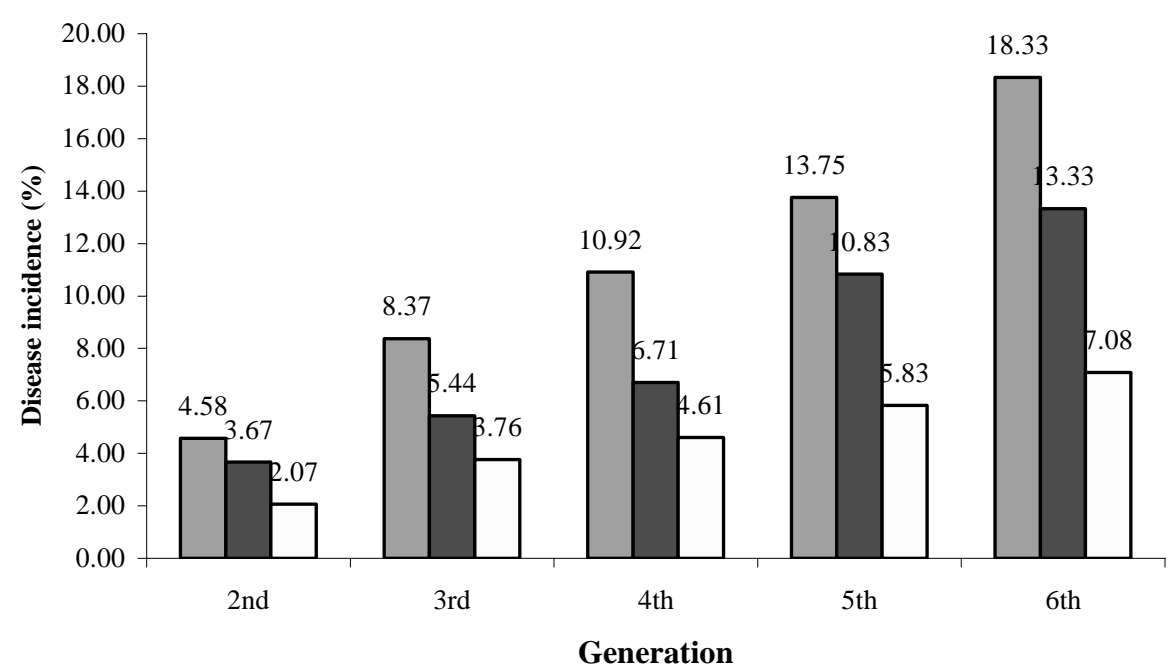

Fig. 2. Incidence of PVY, PLRV and mixed infection of both the viruses on five successive generations of potato grown in 2005-06 crop season. 


\section{Plant height}

The plant height in all the generations of potato grown from healthy tubers was significantly higher as compared to plants grown from PVY or PLRV infected tubers. In case of PVY infected seed tubers of second to fifth generations significantly $(\mathrm{P}=0.05)$ shorter plants were produced as compared to those grown from tubers infected with PLRV in crop season 2004-05 The height of plants grown from tubers infected with both viruses decreased significantly with the progress of generations (Table 1). In case of healthy tubers, significantly longest plant was recorded in second generation, which was followed by third, fourth, and fifth generations. Significantly the lowest plant height was recorded in first generation.

It was found that height was reduced in plants raised from PVY and PLRV infected tubers. The reduction in plant height due to seed infection with PVY was $27.87 \%, 28.49 \%, 32.90 \%$, and $35.12 \%$ in $2^{\text {nd }}, 3^{\text {rd }}, 4^{\text {th }}$, and $5^{\text {th }}$ generations, respectively, as compared to healthy seed. The height reduction due to PLRV infection was $16.05 \%, 17.43 \%, 18.38 \%, 20.30 \%$, and $22.68 \%$ in $1^{\text {st }}, 2^{\text {nd }}, 3^{\text {rd }}, 4^{\text {th }}$, and $5^{\text {th }}$ generation, respectively (Fig. 3).

Results of the study show that in general, the plant height was drastically reduced due to seed tuber infection by either of the two viruses. However, the reduction was severe in case of PVY infection in all the five generations compared to PLRV infection. The lowest plant height recorded in first generation might be due to problem in adaptation of the plants grown from newly imported seed tubers.

Table 1. Plant height of potato grown from different generations of healthy, PVY and PLRV infected tubers during 2004-05 crop season.

\begin{tabular}{l|l|l|l}
\hline \multirow{2}{*}{ Generation } & \multicolumn{3}{|c}{ Plant height $(\mathrm{cm})$} \\
\cline { 2 - 4 } & Healthy & PVY & PLRV \\
\hline $1^{\text {st }}$ & $53.01 \mathrm{~d}$ & - & $44.50 \mathrm{~g}$ \\
$2^{\text {nd }}$ & $60.25 \mathrm{a}$ & $43.46 \mathrm{~g}$ & $49.75 \mathrm{e}$ \\
$3^{\text {rd }}$ & $57.46 \mathrm{~b}$ & $41.09 \mathrm{~h}$ & $46.90 \mathrm{f}$ \\
$4^{\text {th }}$ & $55.26 \mathrm{c}$ & 37.081 & $44.04 \mathrm{~g}$ \\
$5^{\text {th }}$ & $54.19 \mathrm{c}$ & $35.16 \mathrm{j}$ & $41.90 \mathrm{~h}$ \\
\hline
\end{tabular}

Means within the same colunm and row having a common letter(s) do not differ significantiy $(\mathrm{P}=0.05)$ by DMRT. 


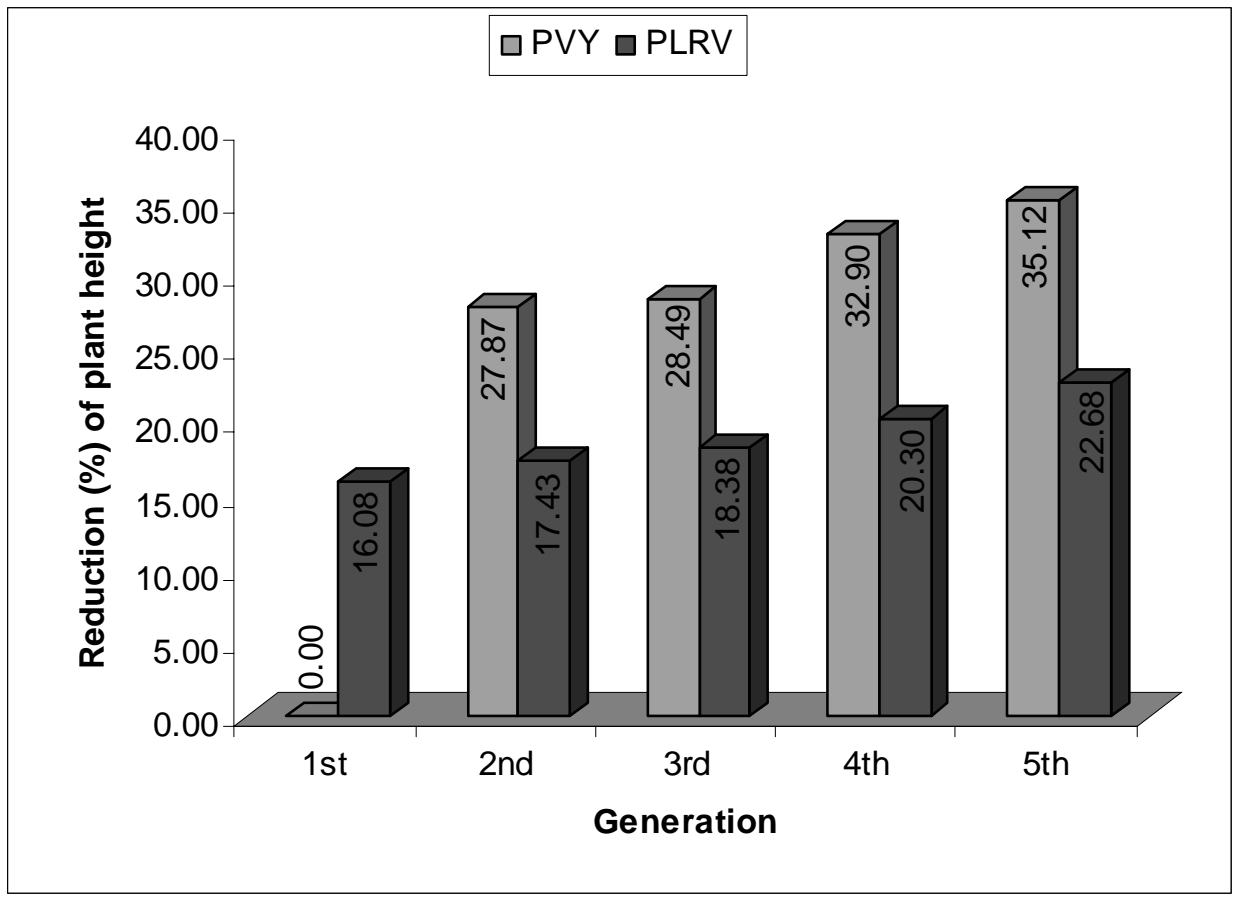

Fig. 3. Percentage of plant height reduction in different generations of potato due to infection of PVY and PLRV during 2004-05.

In cropping season 2005-06, the trend in plant height was almost similar as observed during 2004-05 crop season. The plant height was maximal in the plants grown from healthy tubers compared to PVY and PLRV infected tubers. In case of plants grown from PVY and PLRV infected tubers, the highest plant height of 43.16 and 46.53, respectively, was observed in $2^{\text {nd }}$ generation which was followed by $3^{\text {rd }}, 4^{\text {th }}, 5^{\text {th }}$, and $6^{\text {th }}$ generations (Table 2). Plant height reduction was $27.14 \%, 27.94 \%, 35.06 \%, 46.79 \%$, and $45.60 \%$ due to PVY infection and $21.45 \%, 21.22 \%, 20.86 \%, 21.91 \%$, and $20.61 \%$ due to PLRV infection in $2^{\text {nd }}, 4^{\text {th }}$ $5^{\text {th }}$, and $6^{\text {th }}$ generations, respectively, as compared to healthy plants (Fig. 4). It has been demonstrated that growth reduction and stunting are the two common features associated with the PVY and Pt RV infected potato plants (de Bokx and van der Want, 1987; Rashid et al. 1986). Similar results were observed in the present study.

\section{Number of tubers per hill}

During 2004-05 crop season, the higher number of healthy tubers was recorded in $2^{\text {nd }}$ generation, which was followed by $3^{\text {rd }}, 4^{\text {th }}, 5^{\text {th }}$ and $1^{\text {st }}$ generations Tuber number recorded in $2^{\text {nd }}, 3^{\text {rd }}$, and $4^{\text {th }}$ generations was statistically similar but significantly higher as compared to $5^{\text {th }}$ and $1^{\text {st }}$ generations, where tuber number 
was also statistically similar. However, in all generations, healthy seed tubers yielded significantly higher tuber number as compared to PVY or PLRV infected seed tubers (Table 3). In case of PVY infected seed tubers, the highest number of tubers was obtained from $2^{\text {nd }}$ generation followed by that of $3^{\text {rd }}$ and $4^{\text {th }}$ generations and they differed significantly among themselves. In $4^{\text {th }}$ and $5^{\text {th }}$ generations, tuber number was statistically similar in case of PLRV infection, number of tubers per plants ranged 2.67-5.75 in $1^{\text {st }}$ to $5^{\text {th }}$ generations. The tuber number was maximal in $2^{\text {nd }}$ generation, which was flowed by $3^{\text {rd }}, 4^{\text {th }} 5^{\text {th }}$ and $1^{\text {st }}$ generations (Table 3).

Table 2. Plant height of potato grown from different generations of healthy, PVY and PLRV infected tubers during 2005-06 crop season.

\begin{tabular}{l|l|l|l}
\hline \multirow{2}{*}{ Generation } & \multicolumn{3}{c}{ Plant height $(\mathrm{cm})$} \\
\cline { 2 - 4 } & \multicolumn{1}{|c}{ Healthy } & \multicolumn{1}{c}{ PVY } & \multicolumn{1}{c}{ PLRV } \\
\hline $2^{\text {nd }}$ & $59.24 \mathrm{a}$ & $43.16 \mathrm{~g}$ & $46.53 \mathrm{e}$ \\
$3^{\text {rd }}$ & $58.33 \mathrm{a}$ & $42.03 \mathrm{gh}$ & $45.95 \mathrm{ef}$ \\
$4^{\text {th }}$ & $56.53 \mathrm{~b}$ & $36.71 \mathrm{i}$ & $44.74 \mathrm{f}$ \\
$5^{\text {th }}$ & $54.32 \mathrm{c}$ & $28.9 \mathrm{j}$ & $42.42 \mathrm{~g}$ \\
$6^{\text {th }}$ & $51.29 \mathrm{~d}$ & $27.9 \mathrm{j}$ & $40.72 \mathrm{~h}$ \\
\hline
\end{tabular}

Means within the same column and row having a common letter(s) do not differ significantly $(\mathrm{P}=005)$ by DMRT.

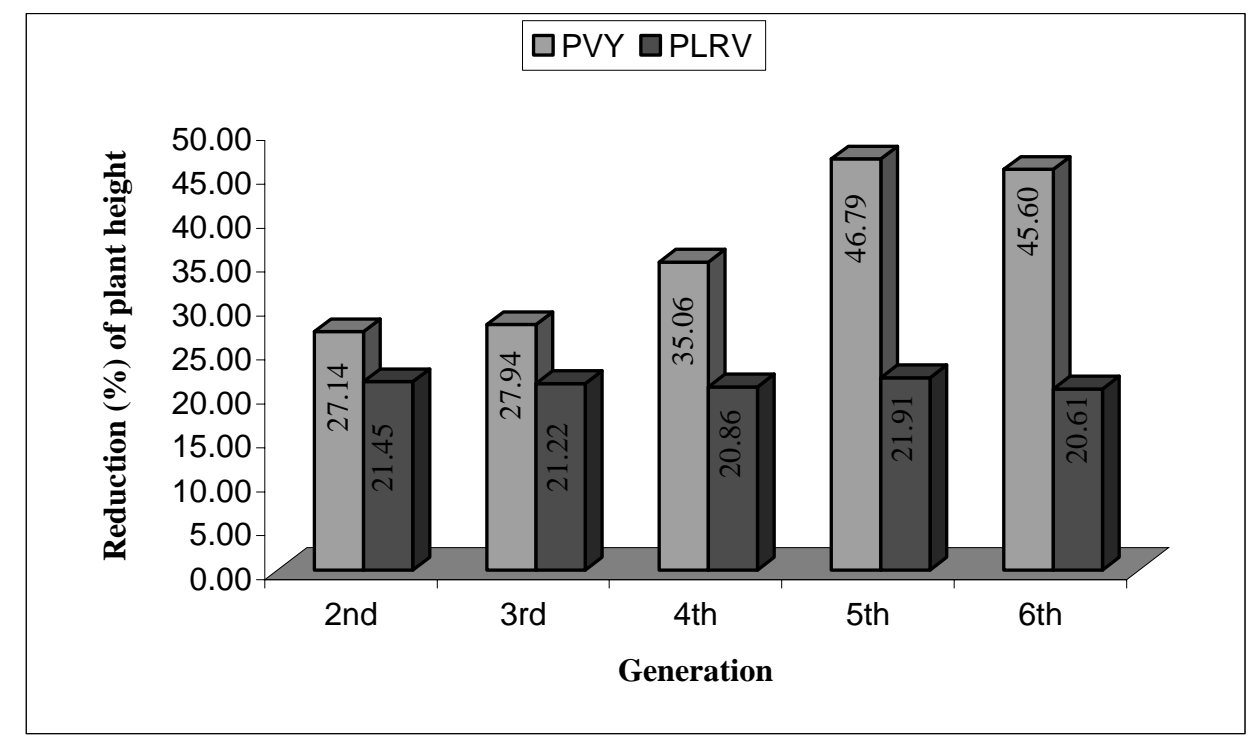

Fig. 4. Percentage of plant height reduction in different generations of potato due to infection of PVY and PLRV during 2005-06. 
Table 3. Number of tubers per hill in different generations grown from healthy, PVY, and PLRV infected tubers during 2004-05 crop season.

\begin{tabular}{|c|c|c|c|}
\hline \multirow{2}{*}{ Generation } & \multicolumn{3}{|c|}{ Number of tubers per hill } \\
\hline & Healthy & PVY & PLRV \\
\hline $1^{\mathrm{st}}$ & $8.07 \mathrm{~b}$ & - & $2.67 \mathrm{gh}$ \\
\hline $2^{\text {nd }}$ & $9.35 \mathrm{a}$ & $5.25 \mathrm{~d}$ & $5.75 \mathrm{c}$ \\
\hline $3^{\text {rd }}$ & $9.13 \mathrm{a}$ & $4.23 \mathrm{e}$ & $4.13 \mathrm{c}$ \\
\hline $4^{\text {th }}$ & 8.99 a & $3.00 \mathrm{fgh}$ & $3.41 \mathrm{f}$ \\
\hline $5^{\text {th }}$ & $8.38 \mathrm{~b}$ & $2.58 \mathrm{~h}$ & $3.10 \mathrm{fg}$ \\
\hline
\end{tabular}

Means within the same column and row having a common letter(s) do not differ significantly $(\mathrm{P}=0.05)$ by DMRT.

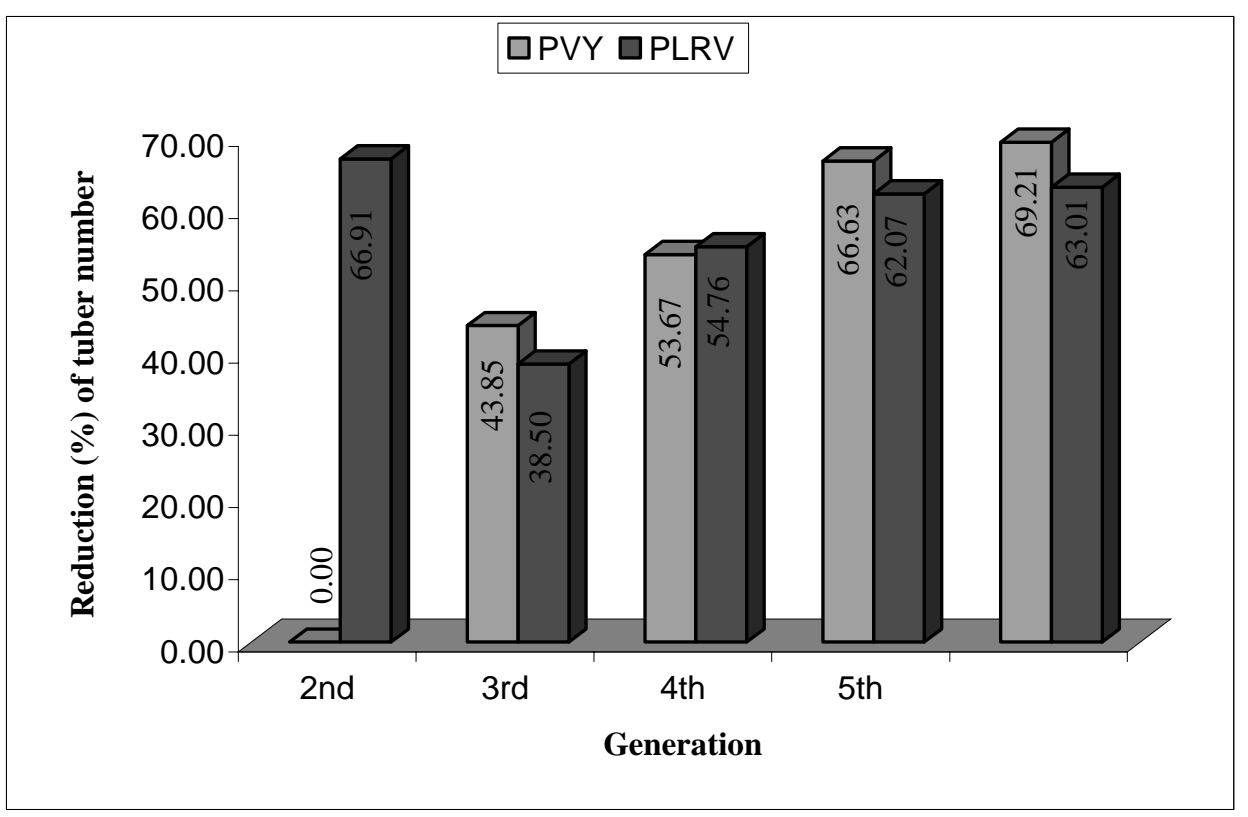

Fig. 5. Percent reduction of tuber number in different generations of potato due to infection of PVY and PLRV during 2004-05. 
Table 4. Number of tubers per hill in different generations grown from healthy, PVY, and PLRV infected tubers during 2005-06 crop season.

\begin{tabular}{|c|c|c|c|}
\hline \multirow{2}{*}{ Generation } & \multicolumn{3}{|c|}{ Number of tubers per hill } \\
\hline & Healthy & $\mathrm{PVY}$ & PLRV \\
\hline $2^{\text {nd }}$ & $9.66 \mathrm{a}$ & $5.31 \mathrm{f}$ & $5.75 \mathrm{e}$ \\
\hline $3^{\text {rd }}$ & $9.16 \mathrm{~b}$ & $3.95 \mathrm{~g}$ & $4.33 \mathrm{~g}$ \\
\hline $4^{\text {th }}$ & $9.02 \mathrm{~b}$ & $2.68 \mathrm{ij}$ & $3.44 \mathrm{~h}$ \\
\hline $5^{\text {th }}$ & $8.35 \mathrm{c}$ & $2.44 \mathrm{ij}$ & $2.82 \mathrm{i}$ \\
\hline $6^{\text {th }}$ & $7.59 \mathrm{~d}$ & $2.28 \mathrm{j}$ & $2.75 \mathrm{i}$ \\
\hline
\end{tabular}

Means within the same column and row having a common letter(s) do not differ significantly $(\mathrm{P}=0.05)$ by DMRT.

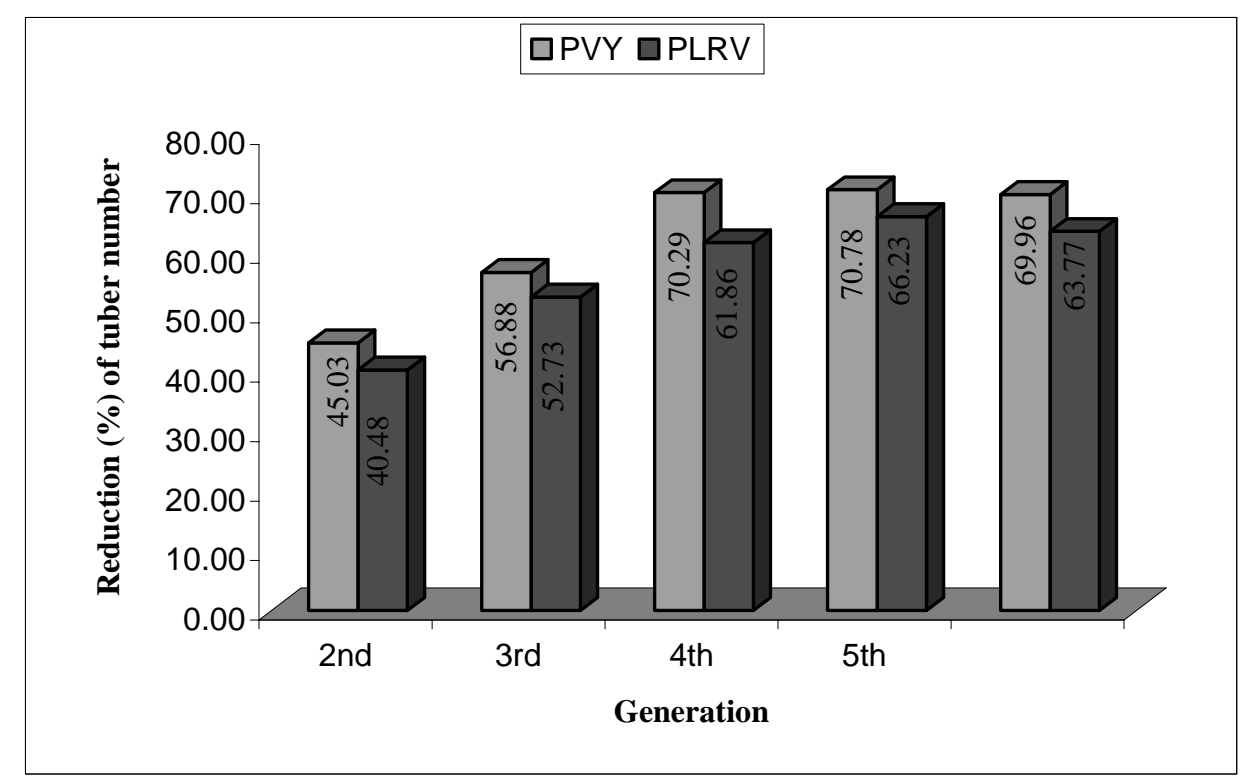

Fig. 6. Percent reduction of tuber number in different generations of potato due to infection of PVY and PLRV during 2005-06.

The reduction in tuber number was 43.85\%. 53.67\%, 66.63\%, and $69.21 \%$ due to PVY infection in $2^{\text {nd }}, 3^{\text {rd }}, 4^{\text {th }}$ and $5^{\text {th }}$ generations, respectively, and $66.91 \%$ $38.50 \%, 54.76 \%, 62.07 \%$, and $63.01 \%$ in case of PLRV infected seed tubers in $1^{\text {st }}, 2^{\text {nd }}, 3^{\text {rd }}, 4^{\text {th }}, 5^{\text {th }}$ generations, respectively (Fig. 5).

During 2005-06 crop season, healthy and PVY or PLRV infected tubers yielded maximum number of tubers in $2^{\text {nd }}$ generation, followed by that in $3^{\text {rd }}, 4^{\text {th }}$, $5^{\text {th }}$, and $6^{\text {th }}$ generations. The number of tubers per hill was significantly $(\mathrm{P}=0.05)$ higher in the plants grown from healthy tubers compared to PVY or PLRV 
infected tubers in all generations (Table 4). Reduction over healthy seed in number of tuber was $45.03 \%, 56.88 \%, 70.29 \%, 70.78 \%$, and $69.96 \%$ due to PVY infection and 40.48\%. 52.73\%. 61.86\%. 66.23\%, and 63.77\% due to PLRV infected seed tubers in $2^{\text {nd }}, 3^{\text {rd }}, 4^{\text {th }}, 5^{\text {th }}$, and $6^{\text {th }}$ generations, respectively. In both the cases the reduction was significantly different in $2^{\text {nd }}, 3^{\text {rd }}$, and $4^{\text {th }}$ generations (Fig. 6).

In general, the number of tuber, per/plant was reduced severely due to seed tuber Infection with PVY or PLRV. The reduction was more severe in case of PVY infection than that caused by PLRV. The reduction in production of potato tuber was reported to be common in PVY or PLRV infected plants. Levy and Marco (1982) reported the cellular changes in potato tuber due to virus infection, which ultimately affected the quality as well as quantity of seed potato production. This result is in agreement with the findings of Broadbent et al. (1962), de Bokx and van der Want (1987), Sanger et al, (1994) and other investigators (Anon., 1990)

\section{Yield of seed potato}

During 2004-05 potalo season, 'when healthy seed rnbers were planted, yield of seed potato (g/plant) was maximal in $2^{\text {nd }}$ generation, which was statistically similar to $3^{\text {rd }}$ generation, but significantly higher as compared to other generations. Tuber yield in $1^{\text {st }}$ and $5^{\text {th }}$ generation was statistically similar but significantly lower compared to $4^{\text {th }}$ generation (Table 5 ). The yield reduction was $53.40 \%$. $76.50 \% 84.60 \%$ and $85.50 \%$ due to PVY infection in $2^{\text {nd }}, 4^{\text {th }}$, and $5^{\text {th }}$ generations, respectively, and $62.50 \%, 50.50 \%, 62.20 \%, 68.70 \%$, and $71.70 \%$ in case of PLRV infected seed tubers in $1^{\text {st }}, 2^{\text {nd }}, 3^{\text {rd }}, 4^{\text {th }}$, and $5^{\text {th }}$ generations, respectively (Fig. 7).

During 2005-06. the maximum tuber yield (g/plant) was recorded in generation, which was followed by $3^{\text {rd }}, 4^{\text {th }}, 5^{\text {th }}$, and $6^{\text {th }}$ generations, irrespective of healthy or virus infected seed tubers. In case of healthy seed, the difference in tuber yield in various generations were significant $(\mathrm{P}=0.05)$. When PVY or PIRV infected seed tubers were used, tuber yield in $2^{\text {nd }}, 3^{\text {rd }}$, and $4^{\text {th }}$ generations was significantly different. The yield in $5^{\text {th }}$ and $6^{\text {th }}$ generations was statistically similar (Table 6). Yield reduction was $69.70 \%, 79.50 \%, 87.07 \%$, 84.54\%, and $83.44 \%$ in case of PVY infection and 52.47\%. 61.81\%, 73.74\%, and 79.73\% due to PLRV infection in $2^{\text {nd }}, 3^{\text {rd }}, 4^{\text {th }}, 5^{\text {th }}$, and $6^{\text {th }}$ generation, respectively, compared to healthy plants (Fig. 8)

Yield reduction was found to be a common phenomenon due to PVY and PLRV infection which has been studied by many investigators. However, some other factors like physiological degeneration may also be involved with the extent of yield reduction in potato. Among the two viruses, PVY was reported to 
be more damaging compared to PLRV (Rohertson, 1978: Stnh and Khurana, 1980: Gupta et al., 1985: Saizar. 1989: Hoa et al., 1991); Hossain and All, 1992; Hamm and Hane. 1999). The results of the present study followed the same trend as described by the authors mentioned carlicr.

Table 5. Yield of seed potato grown from different generation of healthy, PVY, and PLRV infected tubers during 2004-05 crop season.

\begin{tabular}{|c|c|c|c|}
\hline \multirow{2}{*}{ Generation } & \multicolumn{3}{|c|}{ Yield (g/plant) } \\
\hline & Healthy & PVY & PLRV \\
\hline $1^{\text {st }}$ & $388.20 \mathrm{c}$ & - & 145.70 ef \\
\hline $2^{\text {nd }}$ & 530.80 a & $247.30 \mathrm{~d}$ & $262.50 \mathrm{~d}$ \\
\hline $3^{\text {rd }}$ & 490.70 a & $115.40 \mathrm{fg}$ & $185.50 \mathrm{e}$ \\
\hline $4^{\text {th }}$ & $440.90 \mathrm{~b}$ & $67.81 \mathrm{gh}$ & 13.800 ef \\
\hline $5^{\text {th }}$ & 350.80 c & $51.04 \mathrm{~h}$ & $99.75 \mathrm{fgh}$ \\
\hline
\end{tabular}

Means within the same column and row having a common letter(s) do not differ significantly $(\mathrm{P}=0.05)$ by DMRT.

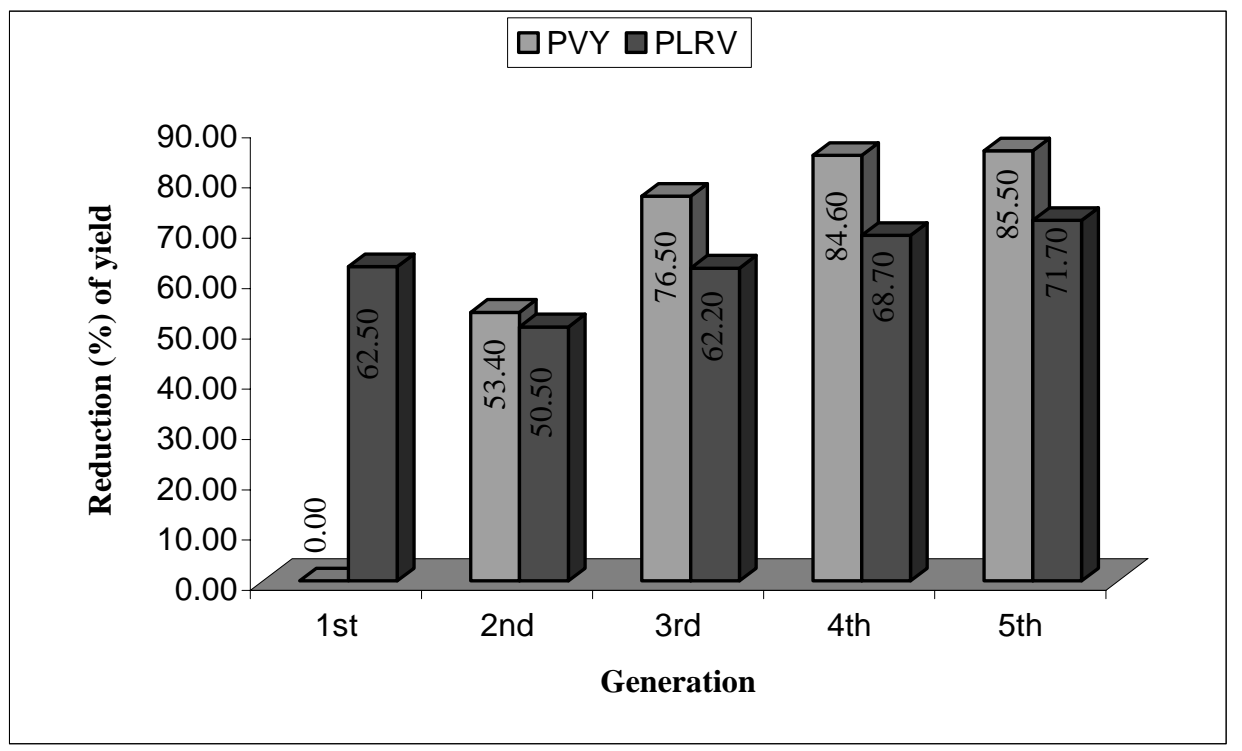

Fig. 7. Percentage of yield reduction in different generations of potato due to infection of PVY and PLRV during 2004-05. 
Table 6. Yield of seed potato grown from different generation of healthy, PVY, and PLRV infected tubers during 2005-06 crop season.

\begin{tabular}{l|lll}
\hline \multirow{2}{*}{ Generation } & \multicolumn{3}{|c}{ Yield (g/plant) } \\
\cline { 2 - 4 } & \multicolumn{1}{|c}{ Healthy } & \multicolumn{1}{c}{ PVY } & \multicolumn{1}{c}{ PLRV } \\
\hline $2^{\text {nd }}$ & $516.80 \mathrm{a}$ & $156.50 \mathrm{~h}$ & $245.60 \mathrm{f}$ \\
$3^{\text {rd }}$ & $486.50 \mathrm{~b}$ & $99.75 \mathrm{i}$ & $185.80 \mathrm{~g}$ \\
$4^{\text {th }}$ & $436.40 \mathrm{c}$ & $56.40 \mathrm{j}$ & $114.60 \mathrm{i}$ \\
$5^{\text {th }}$ & $348.80 \mathrm{~d}$ & $53.63 \mathrm{j}$ & $70.36 \mathrm{j}$ \\
$6^{\text {th }}$ & $305.50 \mathrm{e}$ & $50.58 \mathrm{j}$ & $66.03 \mathrm{j}$ \\
\hline
\end{tabular}

Means within the same column and row having a common letter(s) do not differ significantly $(\mathrm{P}=0.05)$ by DMRT.

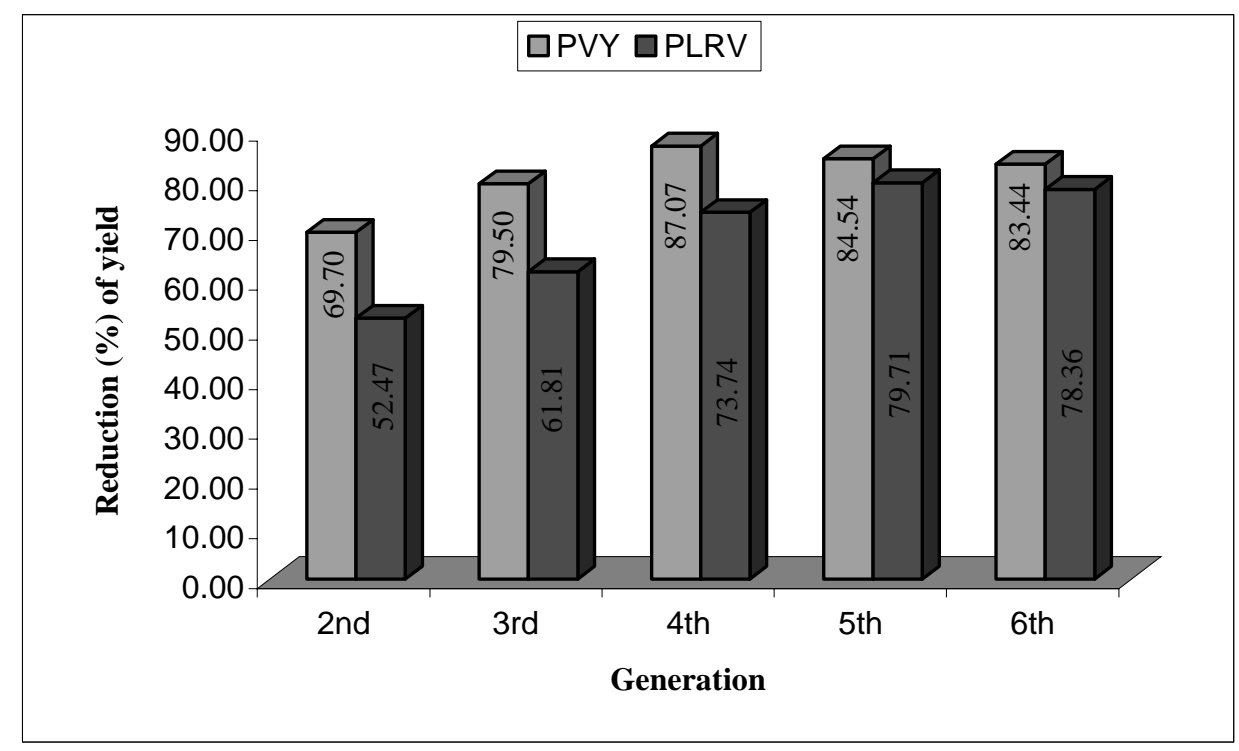

Fig. 8. Percentage of yield reduction in different generations of potato due to infection of PVY and PLRV during 2005-06.

Results of the present investigation clearly show that $2^{\text {nd }}$ generation seed tubers was the best in respect of growth, tuber yield, and yield contributing characters. Incidence of PVY arid PLRV was the lowest in this generation. First generation seed tubers did not perform well which is supported by the findings of Bari et al. (1998). Such low performance in $1^{\text {st }}$ generation might be due to the fact that the newly imported seeds were physiologically too young or they were not well adapted with the new environment of Bangladesh in the first year. Alter acclimatization with the agro-climatic conditions of the country, the variety expressed their yield potential. The reduction in tuber yield after $2^{\text {nd }}$ generation 
seemed to be due to infection of PVY and PLRV. It was continued by the findings that the incidence PVY and PLRV increased, whereas tuber yield decreased with the progress of generations. Therefore, it indicated that in yield performance test of newly introduced potato varieties must be continued at least for two successive generations to record their actual yield potential, and usefulness of introduced varieties decreased with the increase of generations.

\section{References}

Akanda, A.M., K. Tsuno, and S. Wakimoto, 1991. Serological detection of four plant viruses in cucurbitaccous crops from Bangladesh. Ann. Phytopath. Soc. Japan 57: 499-505.

Amtava, K., A. Basu, S.K. Mukhopadhyay, M. Cbettri, A. Konar, and S.K. Pandey. 2001. Population build up of aphids on potato in Burdwan District of West Bcngal. J. Indian Potato Association. 28(1): 123-124.

Anonymous. 1990. Annual Report, 1989-90. Tuber Crops Research Centre (TCRC), BARI, Joydebpur, Gazipur.

Anouymous. 2004. Annual Report 2003-04. Tuber Crops Research Centre (TCRC), BARI, Joydebpur, Gazipur.

Bari, M.A., M.L. Rahman, and M.I. Hoque. 1998. Degeneration in the yield of potato varieties during successive generations. Bangladesh J. Plant Pathol. 14(1-2): 41-43.

Rroadbent. L., G.D. Heathcote and R.C.M. Wright. 1962. Home production of seed for early potatoes, 4. Loss of yield in virus infected plants. Experimental Horticulture 7: 4-6.

Chandla, V.K., K. Shiv, M.N. Singh, K.D. Verma, S.M.P. Khurana, S. Kumar, and S.K. Pandey. 2001. Role of aphids in degeneration of seed stocks in the higher hills. $J$. Indian Potato Association 28(1):117-118.

Choueiri, E., S.E.L. Zammar, F. Jreijiri, D. Mnayer, R. Massaad, A.T. Saad, L. Jianna, and C. Varveri. 2004. Phytosanitary status of potato in the Bekaa valley in Lebanon. Bull. OEPP 34(1):117-121.

Clark, M.F. and A.N. Adams. 1977. Characteristics of the microplate method of enzymelinked immunosorbent assay for the detection of plant viruses. J. Gen. Virol. 34:475483.

de Bokx, J.A. and J.P.H. van dier Want. 1987. Viruses of potatoes and seed potato production. 2nd edn. Pudoc, Wageningen 259pp.

Gupta, B.M., B.P. Sing, H.N. Varma and K.M. Shrivastava. 1985. Perspective, in Plant Virology. Printer House, India 1:1-132.

Hanan P.B. amid D.C. Hane. 1999. Effects of seed borne Potato leaf roll virus on Russet Norkotah potato. Plant Disease 83(12): 1122-1124.

Hill, S.A. 1984. Methods in plant virology vol. 1. Black-Well Scientific Publications. Oxford, London.

Hoa, V.D., F.T. Rasco and P.V. Zaag. 1991. Effect of primary infection of PVY on potato. Asian Pot. J. 2(1) :31-35. 
Hooker, W.J. 1981. Comnpendiwn of potato diseases. American Phytopath. Soc. USA 125p.

Hossain, M. and M.S. Ali. 1992. Effect of potato virus $Y$ seventies on virus concentration, dilution end point and potato yield. Bangladesh .J. Plant Pathol. 8:27-29.

Hossain. M., M.S. Ali, and M.M. Rashid. 1994. Effect of inoculum levels of Potato virus $Y(P V Y)$ on yield and subsequent sprcad of the diseases under insccticidc spray and unspraycd condition. Bangladesh J. Bot. 23:87.

Hossain, M.H. 999. Studies of different aspects of seed tuber infection by PLRV and PVY contributing degeneration of potato. MS Thesis in Plant Pathology, BSMRAU 128pp

Hussain, A., M.H. Ali and A. Waheed. 1972. Degeneration studies in important potato varieties during spring autumn season in Punjab. J. Agril. Res. 10(l):31-37.

Khan, A.L., M.S. Ali, and M.A. Bari. 1991. A review of the viral diseases of potato in Bangladesh. Proceedings of First National Workshop on Tuber Crops, May 28-30, 1989; held at BARI, Joydehpur, Gazpur 286p.

Khurana, S.M.P., S.K. Pandey, U. Bhale, R. L. Patel, and B.S. Lakra. 1998. Degeneration of potato varieties in northern and central India. Indian J. Virol. 14 (21): 111-119.

Levy, D. and S. Marco. 1982. The quality of seed tubers in the Golden Heights for the spring season in Israel. Potato Res. 25(1):107-1 597..

Rashid, M.M., A.L. Khan and M.S. Ali. 1980. Seed Potato Production (In Bengali). Potato Research Centre, BARI, Joydebpur, Gazipur, Bangladesh 156pp.

Robertson, D.G.. 1978. The effect of virus diseases on the yield of potatoes. Proc. of the second Regional Symposium on Potato Production South-East Asia and the Pacific. 5-6 Feb. held at LosBanos, Laguna, Philippines 21p.

Salzar, L.F. 1989. A worldwide problem: Potato virus disease control. C1P circular 17p.

Sanger, R.B.S., H.Q. Agrawal and B,B, Nagaich. 1994. Studies on extent of primary infection of PVX and PVY among tubers of potatoes. Indian J. ViroI. 10(1):22-32.

Sawicka, B. 1994. Degeneration of potato varieties in the South West part of Bialapodlasua region. Fragmeta Agronomica 11 (2):58-65.

Singh, M.N. and S.M.P. Khurana. 1980. Isolation and identification of virus strains and studies on losses in commercial varieties. Ann. Sci. Rept CPR. Simla, India 88-89.

Singh., M.N., S.MP. Kburana, B.B. Nagaich and H.O. Agrawal. 1982. Efficiency of Aphis gossypii and Acyrthosiphan pisun in transmitting potato viruses leafroll and $\mathrm{Y}$. in: Potato in developing countries (B.B Nagaich et al. Eds.) IPA, Simla 89-305.

Tien. P., P.H. Li, and D.L. Tao, 1982. Potato degeneration research in China. American Potato J. 59(11): 46-50.

Wolf, I. and S. Horvath. 2000. The occurrence of potato Y (PVY) potyvirus strains in potato fields in Hungary. Novenyvedelem 36(9):449-455.

Yardimci, N and H. Bostan. 1999. Research on detection of viruses in potato plants tested by ELISA in Erzurum Province. J. Turkish Phytopathology 28(3):99-100. 